\title{
THE METHOD OF HYPNO-CIRCUMCISION IN \\ KLINIK KHITAN PLUS HYPNOSIS IN PABUWARAN PURWOKERTO UTARA SUBDISTRICT
}

\author{
Abdul Mujib \\ Fakultas Dakwah IAIN Purwokerto \\ adulmudo@gmail.com
}

A bstract: This research explains the method of hypno-circumcision in the clinic. Generally, the service of circumcision still uses a conventional method and less of attention tow ard the psychological side. Whereas, this factor is very important on how affecting the patients view's toward circumcision. The main goal of this research is to know the implementation of hypnosis in medical field, especially circumcision process in K linik K hitan Plus Hypnosis Pabuwaran.T he method used in this research is descriptive-analysis. This method is used to provide an overview of the method of hypno-circumcision in K linik $\mathrm{K}$ hitan Plus Hypnosis. This research found that method of hypno-circumcision in K linik K hitan Plus Hypnosis is similar with hypnosis in general. The method of hypno-circumcision into four stages: preparation stage, induction stage, suggestion stage and termination stage. Preparation of hypno-circumcision in K linik K hitan Plus Hypnosis begins from consultation to M s. N ovi as receptionist. Then, Induction is a main way to bring someone from conscious to subconscious mind. Giving suggestion is the core stage in the process of hypno-circumcision. Last stage is termination which defines as a gradual step to bring the subject to consciousness.

Keywords: M ethod; Hypno-Circumcision; and K linik K hitan Plus Hypnosis.

\section{INTRODUCTION}

In Indonesian society, there is a tradition that is specifically designed for children who are becoming akhil baligh (mature), namely circumcision. Often we see in our society, al most all the people held a feast cel ebrating a circumcision. Sometimes, there is a certain person or party deliberately holding massive circumcision.

Circumcision has been done since prehistoric era, known from tradition, such as drawing or symbol in cave wellborn from the StoneA ge and 
resting places of ancient Egypt. The reason for this action is still unclear enoughuntil recent day but some theories predict that this action is a part of a ritual sacrifice or offering to Gods, a sign of submission to the A Imighty, a step into manhood, a sign of defeat or slavery, or an attempt to change the aesthetics or sexuality. ${ }^{1}$

Circumcision is the action of cutting some or all skins which cover the front of the penis. Frenulum ${ }^{2}$ (of penis) can be cut simultaneously through procedure of frenectomies. ${ }^{3}$ The word of circumcision comes from Latin circum (meaning "whirl") and caedere (meaning "to cut"). ${ }^{4}$

Circumcision is obliged for males based upon religious teaching of Islam and Jews. This practice is also found among the majority of the society in South K orea, A merica, and Philippines. ${ }^{5}$ The man who first did circumcision is Prophet Ibrahim, while, on women side is Siti Hajar. God created $A$ dam in circumcised condition. A ccording to a valid chronicle, $A$ braham was circumcised at the age of 80 years. A nother report, which is also valid explains that his circumcision was at the age of $120 .{ }^{6}$

Generally, recent people circumcise their children when they are 8-12 years old. Sometimes, there are children who ask on their own to do so. They feel ashamed because their peers had been circumcised. On the other hand, there are so many children feeling afraid until crying uncontrollably although they are just told by their parents to be circumcised. In this case, anxiety need a special treatment. Somehow, if anxiety gets worst, it will impede the process of circumcision itself.

A ccording to Freud, anxiety involves the perception of unpleasant feeling and physiological reaction. In other words, anxiety is a reaction toward dangerous situations. K artono also reveals that neurosa of anxiety is psychological condition in chronic fear, even no specific stimuli. ${ }^{7}$

In order to cure the children's anxiety before being circumcised, therapy is necessary. One of the technique is hypnosis. ${ }^{8}$ This technique is not a strange one to the recent people. B oth children and adults are often see hypnosis techniques in television performed by hypnotists, such as Romi Rafael, Deni Darko, etc.

B asically the phenomenon of hypnosis (hypnotherapy) has been known since primitive cultures era. In the 18th century, around 1734-1815. M asmer used hypnosis as a way or method of healing on medical therapy. J ean 
$\mathrm{M}$ artin C harcot, ${ }^{9}$ used this method to eliminate the symptoms of patients of hysteria. ${ }^{10}$

Hypnotherapy has a concept that all psychological problems begin from problem in the subconscious mind. A person who is experiencing psychological problem can't control himself because the subconscious mind working automatically and its influence on our behavior are nine times greater than the influence of reason and will. Hypnosis can be applied to physical and psychological problems, especially problems related to thoughts, feelings, and behaviors. Through hypnotherapy, the suggestion given in a state of hypnotic trance, will enter the subconscious and change "mind programs" that exist in the subconscious. ${ }^{11}$

Simply, hypnosis can be defined as a state of relaxation, focus, and concentration. However, lately, hypnosis is reputed as a condition similar to sleep or state of unconscious. ${ }^{12}$ Hypnosis often becomes a popular event that can interest the zest of society when it is packed creatively.

$M$ any people learn and develop hypnotherapy. Some hypnotherapy clinics appear in Indonesia and one of those clinics is owned by A di W. Gunawan. He developed and taught hypnotherapy through Quantum Hypnosis Indonesia (QHI). M aterials and curriculum QHI had officially received an academic recognition and had been taught in the postgraduate of Psychology in one of the private universities in Surabaya. ${ }^{13}$ Then, there is The Winner Institute (TWI), founded by Subur Putra in J alan Raya B aturaden $7^{\text {th }}$ kilometers, 5/VI, B aturaden subdistrict. TW I is a institution that offers motivation training and therapies using semi-hypnotherapy.

The increasing trend of the emergence of Hypnotherapy clinics suggests that this field is important to be studied. The researcher has an interest in a circumcision clinic at B aturaden street $5^{\text {th }}$ kilometers, Pabuwaran, Purwokerto U tara. In this clinic, hypnosis is combined with circumcision. There are several reasons why this place is proper to be researched. First, this clinic has gotten a patent rights of circumcision plus hypnosis. B ecause of this idea and hard work, thousand of children have enjoyed circumcision with comfort and fun. Other benefits are personality improvement and selfdevelopment through suggestion in hypnotherapy. ${ }^{14}$ It indicates that the implementation of hypnosis in medical field has been legalized. In addition, in the wall of clinic, there are three certificates from admitted hypnosis 
institutions, like Indonesian Hypnotherapy A ssociation (IHA) and others displayed.

Second, since the founding of this clinic at three years ago, so many patients come to circumcise their children. Until the end of the day, there are at least four patients per day. In holiday, there are at least ten patients per day. Researcher has made calculation in financial side. O ne patient must pay Rp. 650.000 for getting the service. From M ei $25^{\text {th }}$ until J une $25^{\text {th }} 2013$, there are more than 150 patients, so, the income in that time reach around Rp. 97.500.000. It indicates that hypnosis gets attention from our society if it is well packed. This statement can be associated with our study program to al ways endure, enhance and promote it toward society through hypnosis for instance. Thirdly, based on the early observation, known that the method of hypno-circumcision which is used in the clinic is very simple. It just takes five minutes to make the client ready to be circumcised. ${ }^{15} \mathrm{M}$ oreover the clinic uses alisklamp because other clinics use conventional method. Researcher sees the differences between the use hypnosis in this clinic with TWI for instance.

\section{THEORY OF HY PNOSIS}

Hypnosis is very common in our daily life. Sometimes, it naturally happens. For example, when we are watching television, our attention will be absorbed fully on the TV. Then, we are not aware of our surrounding. In fact, natural hypnosis does not require special preparation to alter brain wave of subject so that they can receive various stimulus or suggestions. This condition (being hypnotized) can be called as hypnotic state.

The word of hypnosis has been used before 1900 by James B raid. ${ }^{16}$ Hypnosis comes from the word "H ypnos" which is the name of the Greek God of Sleep. However, it should be understood that state of hypnosis is not the same as sleeping. Hypnosis is communication activities to take advantage of human subconscious mind with suggestions. For Saiful A nam, hypnosis is a penetration toward critical area of conscious mind and acceptance of certain thinking. W hile, A ndri Hakim said that hypnosis is a state or condition when human tends to be more suggestive. ${ }^{17}$

A merican Society of Clinical Hypnosis ( $\mathrm{ASCH}$ ) states that hypnosis is state of inner absorption, concentration, and focused attention. It is like using a magnifying glass to focus the rays of the sun and make them more 
powerful. Similarly, when our minds are concentrated and focused, we are able to use our minds more powerful. B ecause hypnosis allows people to use more of their potential, learning self-hypnosis is the ultimate act of self control. ${ }^{18}$

Regarding on U.S. Department of Education, Human Services Division, hypnosis is the by-pass of critical factor of the conscious mind followed by the establishment of acceptable selective thinking. ${ }^{19}$

From all defintions above, researcher tends to conclude that hypnosis is the by-pass of critical area through induction to be more suggestive. In this process, brain wave is gradually altered from beta to al pha or theta, that can be seen or measured by electroencepalograph (EEG). Furthermore, the use of hypnosis will be adjusted with its goal. It means that suggestion is accorded with the goal of hypnosis. For example, for patients of circumcision suggestion script contains positive mindset or paradigm in order that they feel comfort in that process.

Now, hypnosis has been fully received as tool of therapy. Hypnosis has been admitted as a method of therapy and legalized by some institutions, i.e. B ritish M edical A ssociation pada tahun 1955, A merican M edical A ssociation pada tahun 1958, dan A merican Psychological A ssociation pada tahun 1960. W hile in Indonesia, hypnosis is still devel oped by some experts.

In hypnosis, there is an al teration of brain wave. Through several researches found that there are four brain waves which can be measure by EEG, namely, beta, al pha, theta, delta. ${ }^{20}$

\begin{tabular}{|c|c|c|c|}
\hline Conscious Area & \multicolumn{2}{|c|}{ Sub-Conscious Area } & Unconscious Area \\
\hline $\begin{array}{c}\text { Beta } \\
(30-14 \text { Hertz })\end{array}$ & $\begin{array}{c}\text { Alpha } \\
(13,9-8 \text { Hertz })\end{array}$ & $\begin{array}{c}\text { Theta } \\
(7,9-4 \text { Hertz })\end{array}$ & $\begin{array}{c}\text { Delta } \\
(3,9-0,1 \text { Hertz })\end{array}$ \\
\hline Normal State & \multicolumn{2}{|c|}{ Hypnosis State } & State Condition \\
\hline $12 \%$ & \multicolumn{3}{|c|}{$88 \%$} \\
\hline
\end{tabular}

This is the explanation of those brain waves:

\section{Beta}

B eta is a brain wave which has the higest frequency, namely between 14 cycles per second (Hertz) until $30 \mathrm{Hertz}$. It is produced by brain when the people are fully awake or when they are in conscious mind. For example, when they are studying and analyzing something. 


\section{Alpha}

The frequency of al pha is around 8 until $13,9 \mathrm{Hertz}$. It produces in more cal $m$ and relaxed condition. A Ipha appears when people start to be passive. Conversely, sub-conscious mind begins active. The focus is directed to one case (internal).

\section{Theta}

Its frequency is around 4 until 7,9 Hertz. It happens when consciousness directs to internal self, i.e. people feel so sleepy. If this condition (theta) has been achieved, it means that sub-conscious mind has been active for replacing conscious mind.

\section{Delta}

The frequency of delta is the slowest one, around 0,1 until 3,9 Hertz. It happens when people enter very deep sleep (somnambulism).

The state of hypnosis can be achieved through several processes. They are pre induction, induction, deepening, suggestion, and termination. For more detail, those steps will be explained below:

\section{Pre-Induction}

All of hypnosis techniques begin from pre-induction. In this stage, a hypnotist expert will asses client and know each other in order to create intimate relationship mentally. ${ }^{21}$ In order to make pre-induction going well, hypnotist must be able to recognize the psychological aspects of subject, such as interest, undesirable things, subject's insight about hypnosis, and so on. Pre-induction can be organized as light conversation and other things that make hypnotist closer to subject mentally. Pre-induction is a critical stage. The failure of hypnosis is often caused by improper pre-induction.

U sually, hypnotists undergo suggestiveness test in this stage. There are four benefits of this test. Firstly, identify the suggestiveness level of subject. Secondly, comprehend the communication level of subject. Thirdly, introduce hypnosis to subject. Fourth, increase the suggestiveness of subject. ${ }^{22}$

2. Induction

Induction is a technique for carrying subject to hypnotic state. ${ }^{23}$ Induction is a main way to bring someone fromconscious to subconscious mind. Generally, technique of induction in relation to time of its use is classified into two, i.e. progressive relaxation, speed induction. ${ }^{24}$ 


\section{Deepening}

This stage is used to deepen the trance state of the subject. The depth of trance is adjusted to need of client. ${ }^{25}$ T here are two types of deepening. First, it is a suggestion that makes conscious mind of subject inactive or relax. Secondly, deepening is a suggestion that brings subject to perform a certain activity, i.e., down the el evator, down the stairs, go to a place, etc. Here is the example of deepening used staircase method.

Spoken to the subject. In a moment I' $m$ going to relax you more completely. In a moment I' $m$ going to begin counting backwards from 10 to 1 .

The moment I say the number 10 you will allow your eyelids to remain closed. The moment I say the number 10 , you will, in your minds eye, see youselfe at the top of a small set of stairs.

The moment I say the number 9 , and each additional number, you will simplymove down those stairs relaxing more completely. A t the base of stairs is a large feather bed, with a comfortable feather pillow.

The moment I say the number one you will simply sink into that bed, resting your head on that feather pillow.

Number 10, eyes closed at the top of stairs. Ten,..

Nine, relaxing and letting go. $\mathrm{N}$ ine...

Eight, sinking into more comfortable, calm, peaceful positions

Seven...

Six... going way down...

Five... moving down those stairs, relaxing more completely.

Four...

Three... breathe in deeply...

Two... on the next number, number one, simply sinking into that bed, becoming more calm, more peaceful, more relaxed.

One.. sinking into that feather bed, let every muscle go limp and loose as you sink into a more calm, peaceful state of relaxation. ${ }^{26}$

\section{Suggestion}

Giving suggestion is the core stage in the process of hypnosis or hypnotherapy. Suggestion must be given accordance with the intent and purpose of the hypnotic process. 27 In hypnotherapy, suggestions are intended to produce a therapeutic effect. In medical field, suggestion will be adjusted to the need of patient, in circumcision for instance, suggestion can be aimed to pain control. For more clear explanation, the script will be written below: 
Pain is warning of your body. You do not to be warned about your (specific pain) any more. You know the problem is there and you are correcting it.

If you want to know about a change, if you need to be warned, you will feel tingling in the area instead. You will then see that any new problem is taken care of.

You no longer feel any pain connected with (specific pain problem) but this in no way alters your warning pain signals for any other reasons.

I want you now to concentrate a healing light in the area where you desire the pain to go away and stay away. Set up rapid and instantaneous healing with the healing light. Feel all tension leaving the area. A II pain is completely gone from the area. Feeling soothed, relaxed and painless. D o not call back the pain. You do not want it. It no longer belongs to you. ${ }^{28}$

In making suggestion script, there are some rules that must be obeyed. They are result oriented, definite, easy to understand, profitable, clear meaning, specific, and no breaking pharsing. ${ }^{29}$

\section{Termination}

Termination in the hypnotic process is a gradual step to bring the subject to consciousness. This process must be undergone completely, so subject will not experience disorientation. There are some terms that have similar meaning, namely awakening and emerging. Saiful A nam prefer to use emerging than others. ${ }^{30}$

Sometimes, subjects are asked to open their eyes before the termination. Furthermore, they are asked to do action in accordance with the suggestions given. In this case, subjects are in a state of ability to open eyes without affecting the trance or open the eyes in a state of trance. Simply, Dave EIman gives emerging technique which so easy and effective:

A the count of three, open your eyes, fully aware, and you feel so comfortable. One...

Two...

Three, open your eyes...

Feel how comfortable your feeling is.

How is your feeling? 
A bdul M ujib: The M ethod of Hypno-circumcision in Klinik K hitan Plus H ypnosis in Pabuwaran...

\section{CIRCUMCISION}

\section{Definition of Circumcision}

The word circumcision comes from L atin circum (meaning "whirl") and caedere (meaning "to cut"). Circumcision is the action of cutting or eliminating some or all skins covering the front of the penis. ${ }^{31}$

In A rabic terms, circumcision comes from khatana- yakhtinu-khatnankhitaanan. It means cutting. In a terminology, circumcisionis differentiated between men and women. A ccording to Imam al-M awardi, scholar of Syafi' i persuasion, circumcision means cutting skin that covers tip of penis to be uncovered. Circumcision is also called as i'zar. Imam an-N awawi, scholar of Syafi'i persuasion, asserts that the form of circumcision which is obliged for men is an action of cutting the foreskin covered head of penis, so it can be opened at all. ${ }^{32}$

A ccording to Imam an-Nawawi, the age for circumcision is not specifically and explicitly determined by Syara'. ${ }^{33}$ It is recommended tocircumcision as soon as possible, even on the seventh day after birth, if the baby is not considered getting dangerous because of it, as done in the $M$ iddle East. In the tradition of the Indonesian I slamic society, especially for boys, M uslims usually circumcise their boys at the age of elementary school, around the age of 6-12 years. ${ }^{34}$

By circumcision, the children are introduced to the health, purity, and cleanliness of the body, especially the genitals to be continually maintained from dirt and unclean behavior.

2. Psychological Impact of Circumcision

Discussion about the advisability of circumcision in western countries that practise circumcision typically has focused on health factors. How ever, recent information about circumcision often disagrees with previous longheld beliefs about the health benefits of circumcision. ${ }^{35}$

There is a contradiction about when circumcision must be done. $0 \mathrm{n}$ the one hand, a baby can be circumcised as soon as possible, if it does not make danger. But, to Ronald Goldman, babies cannot physically resist and stop the circumcision procedure by themselves. A natomical, neurochemical, physiological and behavioural studies confirm that newborn responses to pain are similar to but greater than those in adult subjects. Infants are circumcised with no anaesthesia (reflecting common practice) experience 
not only severe pain, but also an increased risk of choking and difficulty in breathing. ${ }^{36}$

Trauma results in dissociation, a separation of the traumatic experience and associated emotional pain from awareness. B ased on neurological research, painful experience and trauma in childhood can yield in long-term physiological changes in the central nervous system and neurochemical changes. $^{37}$

B ody is a historical repository that remembers everything. The pain of circumcision causes a rewiring of the baby's brain so that he is more sensitive to pain later. Circumcision also can cause post-traumatic stress disorder (PTSD), depression, anger, low self-esteem and problems with intimacy. ${ }^{38}$

Shaykh M ahmud Syaltut, scholars from Egypt, views that circumcision includeijtihad, because there is no nash in holy al-Q ur' an or hadits ${ }^{39}$ which describes the circumcision. Therefore, Syaltut proposed rule that making sick people who are still alive is not allowed in religion, except there are benefits for them exceeding the pain. In this case, the justification is more benefits than harm. ${ }^{40}$

So, researcher thinks that to overcome the psychological impact of circumcision, the doers must know the reason why it is done and know about the advantage of doing it. A merican Pediatrician A ssociation says there are several advantages of circumcision, i.e. circumcision reduces the risk of developing a urinary tract infection (such as bladder infection), reduces the risk of getting some types of sexually transmitted infections (such as HIV), reduces the risk of developing cancer of the penis. ${ }^{41}$

Given that benefits, people will understand and realize how important circumcision is. They will choose the best doctor or clinic to get best service in circumcision. Even if pain still exists, they will think that it is a consequence which is unnecessarily being exaggerated, because it is normal for common people.

\section{IM PLEMENTATION OF HY PNO-CIRCUM CISION METHOD IN KLINIK KHITAN PLUS HYPNOSIS}

\section{Founding of Klinik K hitan Plus Hypnosis}

The idea to build K linik K hitan Plus H ypnosis comes from his (Unggul Senoadji as the founder) interest to $\mathrm{H}$ ypnosis. Since 8 years old, his mother 
has died so helived with his father who was a paramedic. In high spirits, he succeeded in taking education untill sholar in faculty of L aw and became a civil servant in Jakarta. Since childhood, he often saw his father served the society with heart. A that time, his father advised him to build clinic in Pabuwaran. Unggul al ways thinks about his father's message. ${ }^{42}$

Finally, Unggul made a cooperation with his brother who works as a paramedic to build a circumcision clinic. In 2009, he decided to learn hypnosis in Indonesian Hypnosis A ssociation (IHA) in Semarang. Then, Unggul learnt to collaborate with circumcision. His brother circumcised and Unggul hypnotized patients. Unggul decided to be independent and establish Pabuwaran Clinical Hypnosis Plus K hitan who have received patents right on A ugust 17, 2011. ${ }^{43}$

Hetold that he was inspired by Romi Rafael when he watched hypnosis in television. Early, he thought that hypnosis uses magic power, so helooked for information about it in variety sources. Then, he observed each Romi's videos and other hypnosis experts. He noticed their words and movements because he really felt curious to hypnosis.

M r. Unggul views khitan and hypnosis as a combination of medical science and practical psychology. From his experiences, the application of hypnosis in medical field is aimed to eliminate pain and accelerate the healing process in children circumcision. He also learns how the mind works.For him, hypnosis has many advantages:

a. Eliminate fear when face exams, nervous and anxious.

b. Increase motivation to learn something new.

c. Increase professionalism of teachers so when they are teaching, their students can easily absorb the knowledge given.

d. Painless childbirth and circumcision.

e. Improve the minds of the children according to their expectations and dreams.

f. Improve the quality of life.

g. Construct confidence in sale by hipno-selling.

h. A ndeverything related to feelings and thoughts that occur in our lives. ${ }^{44}$

B ecause of his passion for hypnosis, Unggul Senoadji built K linik khitan Plus Hypnosis and got patent right at June $10^{\text {th }} 2011$. His clinic 
located on JI. Raya Baturaden $5^{\text {th }} \mathrm{K}$ ilometers (in front of SDN 1 Pabuwaran), Purwokerto U tara Subdistrict, phone (0281) 625541.

\section{The A pplied M ethod of Hypno-Circumcision in K link K hitan Plus Hypnosis}

To know about the concept of hypno-circumcision in K linik K hitan Plus Hypnosis, researcher observed and interviewed the hypnotists, namely Unggul Senoadji and B angkit. Those people are appropriate to be informants. R esearcher values both of them have so many experiences in applying hypnosis in medical field, especially for circumcision. It can be seen from several certificates related to hypnosis competence displayed on the wall in the clinic.

B ased on interview, there are some points that become principles in the clinic. Unggul said that hypnosis in this clinic is different from others. He said that the overall concept cannot be explained detail, because it is like a "kitchen ingredient" of clinic, like, the prescription of medication. ${ }^{45} \mathrm{~W}$ hen Unggul said that the concept is secret, researcher presumes that he will not allowed outsiders to know about it and not permit researcher to enter the surgical room. N evertheless, he allowed researcher to do observation and to collect data freely. He explained that the concept of hypno-circumcision in the K linik K hitan Plus Hypnosis is simple. There are several steps as following:

a. Building purposes and ask the patient to follow your commands.

b. Induction, guiding the patient into a hypnotic state.

c. B ring up the imagination (to distract).

d. Give suggestions to bring mental anesthesia.

e. Circumcision procedure.

f. Give suggestions for a faster recovery and ending hypnosis. ${ }^{46}$

He said that he also often hold motiva-education in many schools, from el ementary schools up to senior high schools. He showed his skill in hypnosis to gain response and respect from audiences. In this case, he believes that if he can give the best service to clients, automatically clients will share to other people about this "product" from mouth to mouth. This pattern has grown well in our society. That will be very effective way to promote about K linik K hitan Plus Hypnosis, because that is our culture, he added. ${ }^{47}$ 
Like what U nggul told to researcher, the concept of motiva-education which is offered by Unggul Senoadji is similar to the concept of training motivation Subur Putra from The Winner Institute B aturaden. That program is aimed to improve motivation of students in school in which the training is held. If there are students who have certain problems such as smoking, often absent in class and clash among students, they will get more attention from Unggul.

B esides Unggul, B angkit as the hypnotist in the clinic told to researcher some important points about the concept of hypnosis in the clinic. He told their way on how they apply hypnosis in medical field. First, He views that paradigm developed in society as hypnosis. ${ }^{48} \mathrm{H}$ ypnosis is a natural state of mind which everyone can experience it. It is called as natural hypnosis and it is suitable with the theory of hypnosis related to how hypnosis level or state happened.

Natural hypnosis often happens in our daily life. The simple example of natural hypnosis is when we are watching television or listening music or shopping at supermarket. Focusing on something will ignore the others unconciously. A ccording to theory, sub-conscious mind takes and dominates ourselves.

People's mindset has a big role in improving the belief, i.e. if they want to get comfort circumcision, they must go K link K hitan Plus Hypnosis in Pabuwaran. When researcher did observation in the clinic, researcher met a patient and chatted to him. He told to researcher that some of his families have gotten service in K linik K hitan Plus Hypnosis Pabuwaran. He said that the children who were circumcised in the clinic felt glad and satisfied. He thought that circumcision in the clinic is the best for this time. For him, there are two advantages of the clinic, A lisklamp and hypnosis. ${ }^{49}$ Therefore, people are unconsciously hypnotized by socialization and the advertisement. In socialization, they spread the information through billboard, brochures and stickers.

In the billboard, we read the statement which influences people. Patient will get comfortable, enjoyable and fast recovery circumcision. This case is supported by the yellow one that indicates no laser, no sewing, minimum or even no bleeding, etc. For Unggul Senoadji, Alisklamp is the best method in this time. ${ }^{50}$ So that's why, K linik K hitan Plus Hypnosis Pabuwaran uses A lisklamp. 
B asically, there is a polemic of using laser which actually that is electro-cautery. It is known that electro-cautery is most like elements which are heated. Then, there is signal of banning in using this technique for circumcision. Reported from I bnu A bbas from M uhammad saw:

"T hereare three medication, namely bruise, drinking honey and kay (stick hot iron on the wound area), whereas I forbids my followers to get kay. (HR Bukhori)" 51

Second, creating a pleasant place and comfortable place cannot be ignored. For them, this is the key of success because the clients' satisfaction is a priority. Therefore, clinic will get good will from society and clinic will be inundated by ongoing clients. For example, to attract clients, there is photo session that will be discussed later.

Third, set the surgical room enjoyable to make the patients do not see the operation tools. If patients see the operation tools, such as scalpel, hypodermic needle, they will be afraid even having not gotten treatment. $B$ angkit said that it will bother process of circumcision. To increase the pleasure of patients, there is an air conditioner and classic music. M usic can loosen the contraction of muscle. Directly, this clinic is going to alter the negative perception of society toward circumcision.

To make easier in explanation, researcher will discuss the six steps above in four parts, namely preparation, induction, suggestion, and termination.

\section{Implementation of The M ethod of Hypno-circumcision in K linik K hitan Plus Hypnosis}

$M$ ethod is a certain activity related to a way of working. In this research, researcher defines method as a way on how to use hypnosis for circumcision. Further, researcher would like to aprrehend the method of hypno-circumcision which is implemented in $\mathrm{K}$ linik K hitan Plus H ypnosis. Basically, there are four stages:

a. Preparation of Hypno-Circumcision

A ctually, preparation of hypno-circumcision in K linik K hitan Plus $\mathrm{Hypnosis}$ begins from consultation to $\mathrm{M} \mathrm{s}$. N ovi as receptionist. U sually, the patient's family comes to the clinic several days before in order to make a contract on determining the day of getting circumcision. In this clinic there are two services, namely conventional and A lisklamp method. The price of A lisklamp is $R p \quad 650.000$ and conventional is $R p .450 .000$. 
If contract has been made and there is no obstacle, patient must come to the clinic. Then, the patient and his family will be asked to photo session. B epy, as the official, will address equipments. A fter the end of photo session, Wawan or A di as medical officer will ask patient to surgical room to asses or measure the diameter of penis by size-0-meter. Sometimes, various situations may happen. There is a patient on $26^{\text {th }}$ July 2013 , who cannot be circumcised because his penis erected. ${ }^{52}$

M eanwhile, B angkit makes pre-talk to patient. B angkit said there are tw o goals of pre-talk. First, to know the character of patient and make a kind of contract so that patient will follow the hypnosis session without hesitation. Secondly, pre-talk is aimed to create trust from patient. ${ }^{53}$

In order to make pre-induction going well, hypnotist must be able to recognize the psychological aspects of subject, such as interest, undesirable things, subject's insight about hypnosis, so hypnotists usually conduct suggestiveness test in this stage, such as rigid and finger catalepsy.

Rigid and finger catalepsy is the most safe technique in pre-induction. U sually, it is used to show hypnosis phenomenon naturally. The success of this technique depends on the subject itself. The targets of rigid catalepsy are finger, hand, leg, and neck. Hypnotist can give direction tow ard clients in order they can feel rigidity in their body. This technique can be used to train client to imagine as if feel rigidity of certain parts of their body. ${ }^{54}$

During observation, B angkit never practiced that test because it is not necessary and it wastes the time. He said that to know the characteristic of patient can be gotten from conversation. For pre-induction, B angkit spent around one minute. From several patients, researcher noticed that patient is offered to get pleasant circumcision. Bangkit said to his patient,"Would you like to get a comfortable circumcision?" Patient said, "Yes." B angkit continued, "D o you want me to help you?" Patient answered, "Yes, I do." Bangkit told to patient that if you want to get that, you just have to follow what I am talking to you, ok? "Ok," patient answered. (then, Bangkit continue to next stage, like invite patient to pray)..$^{55}$

W hat has been done by Bangkit is same with what has been done by James $B$ raid when the first time he founded hypnosis. At that time, B raid gave the patient some commands, telling him to close his eyes and go to sleep and patient comply it. By eye fixation research, B raid found other 
things that are not found by $M$ esmer. B raid rejected existence of magnetism in human body. He explained that hypnotic state is not caused by magnet field but "neuro-hypnotism" which happens at focusing on certain object. ${ }^{56}$

A ctually, benefits of hypnosis for pain relief (anesthesia) has been known for hundreds of years, even before the use of chemical anesthesia in the medical world. A round 1837 the mental anesthesia was first introduced by a B ritish doctor named J ohn Elliotson. J ohn Elliotson step is followed by J ames Esdaile. In the undiscovered chemical anesthesia, J ames Esdaile has successfully performed thousands of minor surgery without pain and hundreds of major surgery without pain. ${ }^{57}$

Then, researcher analyzes the pre-induction which is done by B angkit. It is not backlash with the idea of pre-induction in chapter II. Pre-induction can be organized as light conversation and other things that make hypnotist closer to subject mentally. B ased on interview, there are two situations that need specific treatment, first, when he faced the children who had critical thinking through their questions and protests, secondly, when he faced the children who had trauma toward something in the past or toward the medical tools such as hypodermic needle and scissors or toward blood. Sometimes, patients al so felt afraid to the circumcision because their mind has been filled by negative assumptions such as the story about the pain from their friends. ${ }^{58}$

A ccording to B angkit, to solve that kind of circumstances, there will be some solutions. First, to handle the children who have critical question, he only has to answer those questions in good manner. B asically, those questions come from their curiosity. It means, B angkit must decrease it in order that circumcision run w ell. Then, B angkit will cure the trauma as soon as possible in two ways. First, motivate and convince the patient that something which makes them afraid is irrational. Secondly, cure them by al tering their negative mindset to right one. ${ }^{59}$ In this case, the way to alter the mind state can be called as counseling.

b. Induction Stage of Hypno-Circumcision

B angkit will ask patient to lie down on the surgical bed. Then, patient open his pants. While medical officers prepare the tools for circumcision, B angkit stand up besi de the patient to do induction. It needs approximately two minutes. Patient will be asked to take a deep breath and exhal e slowly through the mouth. Then, he will ask patient to close his eyes and listen 
carefully to what he is saying. B angkit said it to patient with clear pronunciation and appropriate intonation. ${ }^{60}$

B angkit did not use progressive relaxation which demand relaxation all of the part of body. ${ }^{61}$ That technique cannot be applied in circumcision because of the restrictiveness of time. M oreover, we never know accurately whether client enters trance state or not, because physical relaxation is not the way to hypnosis trance. Further, this way cannot be applied to critical mind, busy and hard work people.

In the beginning, B angkit never forgot for guiding the patient to pray ta'awudz, basmalah, and syahadatain..$^{62}$ It involved a kind a guidance toward patients. A fterward, B angkit demands patients to relax their body and invites patients to use their imagination as if they are in the place where they can feel comfort, such as beach, mountain, etc. To support it, B angkit will turn on the classic music, such as koi relaxation music. Hereis the script that gotten from observation:

Now I ask you to stay focused on my voice, ignoring other sounds, and now, while you remain comfortable, I ask you to use the power of your mind. Imagine it clear that you' re at an absolutely lovely place. Give a clear picture, give a clear color, and enjoy the scenery. L et's continueto spread good feeling and you feel every breath, you continue to make you feeling more comfortable. Just enjoy the wind, and for no apparent reason, you enjoy the comfort, you continued to be more relaxed and deeper.

A fter that, B angkit steps to do deepening, he usually uses count down as following:

I will continue to help comfort multiplied it, and while you remain comfortable, I would invite you to count backwards from five to zero. L ater in the count to zero once you feel so comfortable. I magine the number, five... four... three.. two.. one.. pull a deep breath, exhale slowly, enter your subconscious much deeper and comfortable. ${ }^{63}$

A round at 04.00 p.m., Saturday, $6^{\text {th }}$ J uly 2013 , there is a patient and his name is D oni. A that time, B angkit asked D oni to imagine his own favorite game. ${ }^{64}$ A fter patient experienced rapid eye movement as the sign of hypnotic trance, B angkit said, "Ok. Right now, I ask you to imagine your favorit game. What your favorite game? A nd where are you now?" Patient answered, "I am playing football. I am in the field." 65

It is appropriate with the concept the work of human mind. Imagination is al ways stronger than rationality. Conscious mind is the part of our 
mind which is responsible for analyzing and thinking rationally. Inside it, there is something called will power. Substantively, will power does not have influence toward human life. In fact, no one can be changed by will power. On the contrary, sub-conscious mind is an area which is dominated by feeling, imagination and emotion. It means, using imagination is more effective than using rationality in altering brain wave from beta to al pha or theta.

M edical officers circumcise the patients in this stage. A di or Wawan do first injection as chemical anesthesia when the patients have been seen cal $m$ and comfortable or when the patients experience rapid eye movement as the sign entering hypnotic state. Then, medical officer will cut the frenulum by scalpel and put A lisklamp in the penis. The size of A lisklamp is suitable with the penis size according with the measurement at preparation stage. The process takes approximately ten minutes for A lisklamp and fiveteen minutes for conventional method. ${ }^{66}$

c. Suggestion of Hypno-Circumcision

For B angkit, all of the words that are given to patient are suggestion. He used positive statement to prevent the pain which is experienced by patient of circumcision. We are not all owed to say negative words or to say the words that imply pain itself, such as no pain, no problem, just little pain etc.

In hypnotic state, if patients heard negative words, they will reject them and only respond the word after that. For example, no pain, patients will neglect "no" and respond "pain", it means they will imagine about pain which possibly direct them to feel pain along circumcision process.

What $B$ angkit said to patients is as following "I am very proud of you, you are a great kid. I will give you some information that will be benefit for your future. Today, you have been circumcised, starts from now, you become a pious kid, means you obey your parent and religious teaching. Starts from now, you become more active, easier to understand and memorize subject in learning." ${ }^{67}$ These suggestions show to us that hypnosis is not in contradiction with the value of Islam. It breaks the assumptions from society that underestimate, degrade and oppose hypnosis.

$B$ ased on the observation and interview, there are several suggestions which are usually delivered to patients: ${ }^{68}$ 
1) Become pious children who obey the rules of religion and their parents. Sometimes, children have some problems related to their relation toward their parents so this suggestion will create a better condition.

2) Become more diligent to pray. Pray is an obligation of M oslem that must be built as soon as possible. From interview, some parents said that their children are lazy enough to do five times prayer. Those people said that it is a good suggestion.

3) Become enthusiastic in learning. It generates motivation to study more.

4) Become comfortable in healing the wound of circumcision.

If we look the theory of suggestion, there will be an additional value because $B$ angkit always ask patients to pray before getting circumcision. It automatically rejects assumptions or opinions which regard hypnosis as a negative thing.

d. Termination of Hypno-Circumcision

Termination is the last stage in hypno-circumcision in $\mathrm{K}$ linik K hitan Plus Hypnosis. Bangkit used Dave EIman technique which is known as a simple and effective way to emerge patient.

I will count one to five, at the count of five, I ask you to open your eyes, get back on your self completely. A nd when you open your eyes, say thank God, for no apparent reason, later on when you say thank God, you feel so comfortable once, your body really feels very fresh and very relaxed than ever. One back on me completely, two, do you feel it's getting uncomfortable. Three, your body continues to become more and more fresh. Four, you get ready to open your eyes to the joy and happiness that is extraordinary. Five, thank God. ${ }^{69}$

There are some modifications if we see how B angkit doing termination. First, he used longer count. A ccording to theory, Dave Elman used only one until three. R esearcher appraises to $B$ angkit action in evolving it well. L onger count is needed to prepare the readiness of patients after experiencing hypnotic state. Second, saying thanks to God is a valuable thing in order to plant the religious teaching of Islam toward patients, moreover they are still children. Internalization of religion belief will be more effective in children than adults.

One thing that cannot be forgotten is when patients did not aware that they have been circumcised. All of them are al ways asked about their goal come to the clinic. Bangkit said to patient "W hat is your goal here?" "To 
be circumcised", patient answered. "Do you want to get it right now or later?" Bangkit asked again. Patient answered, "Right now" (At the moment, Bangkit showed to patient that he has been circumcised. Patient was seen surprised because he did not know when the process happened). ${ }^{70}$ Then, $B$ angkit said to patient in order to obey all of the rules that make the healing faster. For example, do not play football for certain day, keep the cleanness of penis and its area, and drink the medicine as direction. If something bad happen, such as ulceration, patient can get more treatment freely. Clinic will responsible for anything along healing time.

The method of hypno-circumcision in K linik K hitan Plus Hypnosis in Pabuwaran consists of four stages. Every stage must be done well because it will affect the process of circumcision. B ased on observation, the patients who exit from surgical room were looked well. They smiled to their family and laughed with their peers. Therefore, hypnosis is very important to be implemented in circumcision because it can relieve the pain and make patients relax.

\section{CONCLUSION}

Researcher concludes that the implementation of hypno-circumcision in K linik K hitan Plus Hypnosis in Pabuaran Purwokerto U tara Subdistrict proceed into stages. They are preparation, induction, suggestion and termination.

1. Preparation of Hypno-circumcision

B angkit makes pre-talk to patient. Bangkit said there are two goals of pre-talk. First, to know the character of patient and make a kind of contract so that patient will follow the hypnosis session without hesitation. Second, pre-talk is aimed to create trust from patient.

2. Induction of Hypno-circumcision

Induction is a main way to bring someone fromconscious to subconscious mind. In the clinic, patient will be asked to take a deep breath and exhale slowly through the mouth. Then, he will ask patient to close his eyes and listen carefully to what he is saying.

3. Suggestion of Hypno-circumcision

Giving suggestion is the core stage in the process of hypno-circumcision. To B angkit, all of the words that are given to patient are suggestion. 
He used positive statement to prevent the pain which is experienced by patient of circumcision. We are not allowed to say negative words.

4. Termination of Hypno-circumcision

Termination is the last stage in hypno-circumcision in $\mathrm{K}$ linik $\mathrm{K}$ hitan Plus Hypnosis. Termination is a gradual step to bring the subject to consciousness. B angkit used Dave EIman technique which is known as a simple and effective way to emerge patient.

\section{ENDNOTES}

${ }^{1}$ http://id.wikipedia.org/wiki/ (downloaded at M ei $20^{\text {th }} 2013$ at 01.00 p.m).

2 Ibid.

${ }^{3}$ Frenulum is the membrane of foreskin and the shaft of penis.

${ }^{4}$ Frenectomies (frenectomy) is the surgical removal or repositioning of the frenum.

${ }^{5} \mathrm{http}: / /$ id.wikipedia.org/wiki/ (downloaded at M ei $20^{\text {th }} 2013$ at 01.00 p.m). ${ }^{6}$ Ibid.

${ }^{7}$ http://lbm.mudimesra.com/2011/09/.html. The content of two different traditions is apparently incompatible, but between those val id (shaheh) traditions can be compromised by understanding 80 -years from his prophetic, while his circumcision at the age of 120 years, that is from the year of his birth.

${ }^{8}$ Trismiati, In J ournal of Psychology, "Perbedaan Tingkat K ecemasan A ntara Pria dan Wanita A kseptor K ontrasepsi M antap di RSU P D r. Sardjito Yogyakarta". Faculty of Psychology, University of Gadjah M ada, Y ogyakarta.

${ }^{9}$ The term hypnosis was first triggered by James B raid in 1843 in his book Neurypnology or The Rationale of Nervous Sleep Considered in Relation With A nimal Magnetism in wikipedia.

${ }^{10} \mathrm{~J} \mathrm{ean} \mathrm{M}$ artin Charcot (1825-1893) born in Paris, France, is a neurologist and professor of anatomical pathology, $\mathrm{He}$ is also known as the father of modern neurology.

${ }^{11}$ A de Yuniarti, 2012, M etode Hipnoterapi the Winner Institut, research. In Pavel Sovodka, Secret of Hypnotherapy, (J akarta: Flash B ook, 2010) p. 16.

$12 \mathrm{M}$ aestro hipnotis http://.com / definition-hypnosis.html (downloaded at $\mathrm{M}$ ei $20^{\text {th }} 2013$ at 13.00 wib).

${ }^{13}$ Willy Wong and A ndri Hakim, Dahsyatnya Hypnosis, (Visimedia, 2009, Yogyakarta), p. 3.

${ }^{14} \mathrm{~A}$ di W. Gunawan, Hypnoterapi the A rt of Subconcious Restructuring, (Jakarta: PT. Gramedia Pustaka B aru), p. 11.

${ }^{15}$ Interview with Bangkit, on Wednesday, June $19^{\text {th }} 2013$ at 03.00 p.m.

${ }^{16}$ Interview with B angkit, on Friday, J une $26^{\text {th }} 2013$ at 04.15 p.m. 
${ }^{17}$ J ames B raid (on J une $19^{\text {th }} 1975-\mathrm{M}$ arch $25^{\text {th }} 1860$ ) a Scottish surgeon and scientist. He is regarded by many as the first genuine "hypnotherapist" and the "Father of M odern Hypnotism. (http: Wikipedia.org accessed on Tuesday, July $16^{\text {th }}$ 2013 at 08.40 a.m.)

${ }^{18}$ A ndri Hakim, Hypnosis in Teaching, Cara Dahsyat M endidik dan M engajar, Jakarta: Visimedia, 2011, p. 1.

${ }^{19}$ www.asch.net (downloaded on thuesday, J une $25^{\text {th }} 2013$, at 19.31 p.m.)

${ }^{20}$ www.indramajid.com, M engenal Hipnotis M odern

${ }^{21}$ Willy Wong and A ndrew Hakim, Dahsyatnya Hypnosis, (Yogyakarta: Visimedia 2009), p. 20.

22 Ibid., p. 81.

${ }^{23}$ Willy Wong and A ndrew Hakim, Dahsyatnya Hypnosis, (Yogyakarta: Visimedia 2009), p. 197.

${ }^{24}$ Ibid., p. 36.

${ }^{25}$ SaifulA nam, 4 jam Pintar Hipnosis, ... , p. 93.

${ }^{26}$ Ibid., p, 114.

${ }^{27}$ Hypnosis\& hypnotherapy scripts, A ustralia's Hypnosis O nline, p.56 www.hypnosisonline.com.au (accessed on Wednesday, J uly $3^{\text {tr }} 2013$ at 11.00 a.m.)

${ }^{28}$ Willy Wong and A ndrew Hakim, Dahsyatnya..., p, 45.

${ }^{29}$ Hypnosis \& hypnotherapy scripts, A ustralia's Hypnosis O nline, p. 56 at www.hypnosisonline.com.au (accessed on Wednesday, J uly $3^{\text {tr }} 2013$ at 11.00 a.m.)

${ }^{30}$ SaifulA nam, 4 jam Pintar Hipnosis, ... , p. 166.

${ }^{31}$ http://id.wikipedia.org/wiki/ (A ccessed on Friday, A pril 19 ${ }^{\text {th }}$ 2013)

${ }^{32}$ Setiawan Budi U tomo, Fiqih A ktual J awaban Tuntas M asalah K ontemporer, (Jakarta: Gema Insani, 2003), p, 286.

${ }^{33}$ It means Islamic law according to any recognized mazhab.

${ }^{34}$ Setiawan Budi U tomo, Fiqih A ktual..., p. 288.

${ }^{35}$ R. Goldman, "The psychological impact of circumcision", BJU International (1999), 83, Suppl. 1, 93-102, Circumcision Resource Center, B oston, M assachusetts, USA (http://onlinelibrary.wiley.com/doi/10. pdf, accessed on Tuesday, July $23^{\text {th }} 2013$ at 15.09 p.m.)

36 Ibid., p, 93.

37 Ibid., p, 94.

$38 \mathrm{http} / / /$ ww w.psychologytoday.com (accessed on tuesday, J uly $23^{\text {th }} 2013$ at 15.09 p.m.)

${ }^{39} \mathrm{H}$ adits is traditional collection of stories relating words or deeds of M uhammad the chief source of guidance for understanding religious questions.

${ }^{40}$ Setiawan Budi U tomo, Fiqih A ktual..., p. 288.

${ }^{41} \mathrm{http} / / /$ ww w.psychologytoday.com (accessed on tuesday, $23^{\text {th }}$ J uly 2013 at 15.09 p.m.).

${ }^{42}$ Interview with Unggul Senoadji on M onday July $22^{\text {th }} 2013$ at 04.00 p.m.

${ }^{43}$ Ibid. 
A bdul M ujib: The M ethod of Hypno-circumcision in K linik K hitan Plus Hypnosis in Pabuwaran...

${ }^{44}$ Opinion of U nggul Senoadji can be seen completely in his facebook account, namely Unggul Senoadji.

${ }^{45}$ Interview with Unggul Senoadji, J une $26^{\text {th }}$ 2013at 10.00 a.m.

${ }^{46}$ See M edical Hypnosis in appendix.

${ }^{47}$ Interview with Unggul Senoadji, J une $26^{\text {th }} 2013$ at 04.00 p.m.

${ }^{48}$ Interview with B angkit, J une $29^{\text {th }} 2013$ at 05.00 p.m.

${ }^{49}$ Interview with Sabar Harno, J uly $22^{\text {th }} 2013$ at 04.30 p.m.

50 Interview with Unggul Senoadji, at J uly 26 2013 at 04.00 p.m.

${ }^{51}$ In Shahih Bukhori chapter II: Penyembuhan Dengan Tiga Cara, 1963 (Bukhori, 5681).

${ }^{52}$ Observation in the clinic on Friday July $26^{\text {th }} 2013$ at 04.00 p.m.

${ }^{53}$ Interview with B angkit N ur Rahmat on M onday, July $22^{\text {th }} 2013$ at 09.00 a.m. ${ }^{54}$ Willy Wong and A ndri Hakim, Dashyatnya..., p. 26.

${ }^{55}$ Observation in surgical room on Wednesday July $24^{\text {th }} 2013$, at 05.00 p.m.

${ }^{56}$ Willy Wong and A ndri Hakim, Dahsyatnya... p. 204.

${ }^{57}$ See M edical Hypnosis 2009 Guideline.

${ }^{58}$ Interview with Bangkit Nur Rahmat on Tuesday, July 23rt 2013 at 04.30 p.m.

$59 /$ bid.

${ }^{60}$ This opinion based on observation along the research.

${ }^{61}$ Observation in the surgical room from July $22^{\text {th }}-27^{\text {th }} 2013$.

${ }^{62} T a^{\prime}$ awudz means $A^{\prime}$ udzubillahi minassyaithonirrojiim. Basmalah means bismillahirrohmaanirrohiim. Syahadatain means asyhadu anla ilaaha illalloh wa asyhadu anna muhammadar rasuulullah.

${ }^{63}$ lbid.

${ }^{64}$ Observation in the clinic on Saturday J uly $6^{\text {th }} 2013$ at 04.00 p.m.

${ }^{65}$ Observation in the surgical room on Thursday J uly $25^{\text {th }} 2013$ at 03.30 p.m.

${ }^{66} \mathrm{O}$ bservation along the research in surgical room of K linik $\mathrm{K}$ hitan Plus Hypnosis.

${ }^{67}$ Observation in the clinic on Tuesday, July $23^{\text {th }} 2013$ at 04.25 p.m.

${ }^{68}$ Observation in the clinic along research.

69 Ibid.

${ }^{70} \mathrm{O}$ bservation in the surgical room along the research.

\section{BIBLIOGRAPHY}

A Imiatin, Isma M D. (2010). Dahsyatnya Hypnosis L earning, untuk Guru dan Orang Tua, Hipnosis untuk Pembelajaran di Sekolah dan Pengasuhan A nak di Rumah. Yogyakarta: Pustaka Widyatama. 
A nam, Saiful. (2010). 4 Jam Pintar Hipnosis, dari M engenal Istilah, Konsep, Tahapan, Teknik, Sugesti, hingga Panduan Praktik Hipnosis. J akarta: Visimedia.

A rif, A ntonius. (2011). The Handbook of Hypno Therapy, Scripts and Strategies. Jakarta: Gramedia.

A rikunto, Suharsimi. (2002). Prosedur Penelitian Suatu Pendekatan Praktek, Yogyakarta: Rineka Cipta.

A zwar, Saifuddin. (1998). M etodologi Penelitian. Yogyakarta: Pustaka Pelajar.

Bayne, Tim."Hypnosis and the Unity of Consciousness", University of Oxford and St. Catherine's College. United Kingdom (tim.bayne (a)gmail.com). This paper was published in (2007) Hypnosis and Conscious States, ed. Graham Jamieson (ed.), Oxford: Oxford University Press (93-109). A ccessed on M onday, M ei 20 2013, at 01.00 p.m.

Foley, K athleen. MD, "Dismantling the B arriers: Providing Palliative and Pain Care", Cornell U niversity M edical College, New York, NY, at http://jama.ama-assn.org/cgi/content/full/283/1/118.(A ccessed on M onday, M ei $20^{\text {th }} 2013$, at 01.00 p.m.).

Giles,C. Scot. "A M ethod for using Hypnotism with Persons Living with Cancer, Essay, 2004. A ccessed on M onday, M ei $20^{\text {th }} 2013$, at 01.00 p.m.

Goldman, $R$, The psychological impact of circumcision, BJU International (1999), 83, Suppl. 1, 93-102, Circumcision Resource Center, B oston, M assachusetts, USA (http://onlinelibrary.wiley.com/doi/10. pdf, accessed on Tuesday, July 23 2013 at 15.09 p.m.)

Hakim, A ndri. (2011). Hypnosis in Teaching, Cara Dahsyat M endidik dan M engajar, Jakarta: Visimedia.

Hypnosis\& hypnotherapy scripts, A ustralia's Hypnosis Online, at www. hypnosisonline.com.au. Accessed on Wednesday, July $3^{\text {th }} 2013$ at 11.00 a.m.

K hairah, Fastabiqul. "K hitan: Bagi Laki-laki dan Perempuan," http:// 4moslem.wordpress.com/2008/11/16/khitan-bagi-laki-laki-danperempuan, A ccessed on Tuesday, July 23th 2013 at 03.09 p.m.

M oleong, Lexy J. (2008). M etodologi Penelitian Kualitatif. B andung:

Rosdakarya. 
M uafif. (2007). Pelaksanaan Psikoterapi Islam Terhadap Psikosis (Studi K asus Pondok Pesantren A sy-Syamsiyah D esa Sawangan K ecamatan Alian K abupaten K ebumen. Thesis, STAIN Purwokerto.

M ustofa, A gus. (2011). Energi D zikir, A lam B awah Sadar. Surabaya: Padma Press.

Peynovska, Rumy Dr Jackie Fisher, Dr David Oliver, Prof V.M. M athew, "Efficacy of Hypnotherapy as a Supplement Therapy in Cancer Intervention", European J ournal of Clinical Hypnosis: 2005 volume 6 - issue 1, A ccessed on M onday, M ei 20th 2013, at 13.00 p.m.

Ruslan, Rosady. (2004). M etode Penelitian, Public R elations dan Komunikasi. Jakarta: PT Raja Grafindo.

Shicida, M akoto. (2010). The Mistery of The Right B rain, M engungkap $M$ isteri Otak Kanan untuk M embuat A nak Jadi Jenius. Terj. Femi Olivia. Jakarta: Gramedia.

Suryabrata, Sumadi. (2011). M etodologi Penelitian. Jakarta: PT Raja Grafindo.

Setiawan Budi Utomo. (2003). Fiqih A ktual Jawaban Tuntas Masalah Kontemporer. Jakarta: Gema Insani.

Tanzeh, A hmad. (2011). M etodologi Penelitian Praktis. Yogyakarta: Terras. Trismiati. "Perbedaan Tingkat K ecemasan A ntara Pria dan Wanita A kseptor K ontrasepsi M antap di RSUP Dr. Sardjito Yogyakarta", J ournal of Psychology in Faculty of Psychology, U niversity of Gadjah M ada. Wong, Willy and A ndrew Hakim. (2009). Dahsyatnya Hypnosis. Yogyakarta: Visimedia.

Yuniarti, A de. (2012). "M ethod of Hypnotherapy The Winner Institute", Thesis. STAIN Purwokerto.

wikipedia.org/wiki. A ccessed on M onday, M ei $21^{\text {th }} 2013$, at 01.00 p.m. www.mestrohipnotis.com.A ccessed on M onday, M ei $20^{\text {th }} 2013$, at 01.00 p.m.

ww w.psychologytoday.com, A ccessed on Tuesday, J uly $23^{\text {th }} 2013$ at 03.09 p.m.

ww w.asch.net. A ccessed on thuesday, J une $25^{\text {th }} 2013$, at 19.31 p.m.

www.indramajid.com, "M engenal Hipnotis Modern." A ccessed on thuesday, J une $25^{\text {th }} 2013$, at 19.31 p.m.

www.brightfuture.org. A ccessed on thuesday, J une $25^{\text {th }} 2013$, at 19.31 p.m. 